http://jmscr.igmpublication.org/home/

ISSN (e)-2347-176x ISSN (p) 2455-0450

crossref DOI: https://dx.doi.org/10.18535/jmscr/v8i11.33

\title{
Biomarkers in Sepsis: A study of Procalcitonin as a diagnostic and prognostication tool in Sepsis in a tertiary care hospital
}

\author{
Authors \\ Jyotsnaa $\mathbf{M}^{1}$, Nanjil Kumaran $A^{2}$, Vijayakumar $\mathbf{N}^{3}$, Umarani $\mathbf{R}^{4}$ \\ ${ }^{1}$ Post Graduate, Department of Medicine, RMMCH, Chidambaram-608002, Tamilnadu \\ ${ }^{2}$ Assistant Professor, Department of Medicine, RMMCH, Chidambaram-608002, Tamilnadu \\ ${ }^{3}$ Assistant Professor, Department of Medicine, RMMCH, Chidambaram-608002, Tamilnadu \\ ${ }^{4}$ Professor, Department of Medicine, RMMCH, Chidambaram-608002, Tamilnadu
}

\begin{abstract}
Background: The incidence and mortality from sepsis has been on a rising trend worldwide. Early diagnosis and intervention are key to reducing morbidity and mortality from sepsis. Biomarkers are gaining prominence in this regard. Of these, procalcitonin (PCT) which is elaborated by the tissues in response to the inflammatory response of sepsis, has high sensitivity and specificity to diagnose sepsis.

Aims and Objectives: The study was done with the aim to assess the prevalence of elevated serum procalcitonin levels in patients with sepsis, and to evaluate for correlation of procalcitonin levels with severity of sepsis, clinical course, prognosis (assessed by prognostication scores like qSOFA, SOFA, APACHE II scores) and treatment outcome of sepsis.

Methods: 40 patients admitted with sepsis in the medical ICU of Rajah Muthiah Medical College Hospital during the period from September 2018 to August 2020 were studied. Demographic characteristics, history and physical examination details of the patients were entered in a case proforma. qSOFA score was calculated from GCS, respiratory rate and systolic BP. Shock index was calculated from heart rate and systolic BP. A venous sample for procalcitonin estimation was obtained in first 12 hours. Investigations from workup of the patient and clinical status were used to calculate SOFA and APACHE II score. The clinical course and treatment of the patients were followed up. Statistical analysis of the above data was performed.
\end{abstract}

Results: Among the 40 sepsis patients studied, 20\% had sepsis $(n=8), 40 \%$ each severe sepsis and septic shock ( $n=16$ in each category). The overall mortality was $25 \%(n=10)$, with highest mortality in patients with septic shock. The mean PCT of study subjects was $5.64 \pm 15.05 \mathrm{ng} / \mathrm{ml}$. PCT may be used to predict mortality as survivors had mean PCT of $2.75 \pm 4.10 \mathrm{ng} / \mathrm{ml}$ compared to $14.29 \pm 28.57 \mathrm{ng} / \mathrm{ml}$ in nonsurvivors $(p<0.05)$. Greater PCT values were associated with need for ventilatory support (mean $8.86 \pm$ $21.78 \mathrm{ng} / \mathrm{ml}, p$ <0.05). PCT levels were greater with greater severity of sepsis: the mean PCT was $1.77 \pm$ $2.66 \mathrm{ng} / \mathrm{ml}$ in sepsis, compared to $3.05 \pm 4.29 \mathrm{ng} / \mathrm{ml}$ in severe sepsis, and $10.16 \pm 22.90 \mathrm{ng} / \mathrm{ml}$ in septic shock. qSOFA score and CRP were good independent predictors of mortality $(p<0.05$ and $p<0.0001$ respectively) and showed positive correlation with PCT.

Conclusion: Serum PCT may be used to diagnose sepsis at an early stage. In addition, it is useful to categorize severity of sepsis, predict mortality and need for ventilatory support in patients with sepsis.

Keywords: Sepsis, procalcitonin, biomarkers, septic shock, CRP, SOFA, APACHE II score, shock index, prognostic indicator. 


\section{Introduction}

Sepsis is a dysregulated immune response to infection resulting in organ dysfunction. 13 million cases of sepsis occur each year globally, with 4 million people dying of it. The mortality rate is as high as $29 \%$ in Asian countries ${ }^{1}$.

The risk factors for sepsis include age over 65 years, lower socioeconomic status, male gender, African or Afro-American race, immunosuppressed states like AIDS, malignancy, conditions like diabetes, renal failure and genetic defects in immune functions.

Sepsis develops with the initiation of a proinflammatory cascade in the body following an infection. This results in a systemic inflammatory response syndrome (SIRS). In recent years, a compensatory anti-inflammatory response syndrome (CARS) ${ }^{2}$ has been described, which is associated with decompensation in the immunosuppressed, culminating in severe sepsis and death.

On contact with the infecting organism, the cells of the innate immunity,via their Pattern Recognition Receptors (PRRs) (like Toll-like receptors) recognize and bind PathogenAssociated Molecular Patterns (PAMPs) on the surface of the organism. This binding stimulates signalling through cytosolic nuclear factor - kappa $\mathrm{B}(\mathrm{NF}-\mathrm{\kappa} \mathrm{B})$, promoting transcription and synthesis of proinflammatory cytokines, including $\mathrm{TNF} \alpha$ and IL-1.

The proinflammatory cytokines mediate vasodilatation, activate phagocytes and recruit the coagulation and complement system. The highmobility group protein HMGB1, produced by monocytes and macrophages, has been recognized as a late-acting cytokine ${ }^{3}$, which further aggravates the inflammatory process resulting in severe sepsis.

These cytokines trigger production of C-reactive protein (CRP) by the liver ${ }^{4}$, procalcitonin (PCT) by parenchymal tissues ${ }^{5}$, and themselves may be considered biomarkers of sepsis (e.g., IL-6, IL-8, MCP-1). Bacterial infection ${ }^{6}$ triggers production of PCT via $\mathrm{TNF}^{7}, \quad \mathrm{IL}-1 \beta$ and IL-6(Figure
1).Other biomarkers in sepsis include acute phase reactants like pentraxin 3, complements like $\mathrm{C} 3 \mathrm{~b}$, C5a, neutrophil markers like CD64, CD11b, sTREM1 (soluble form of triggering receptor expressed on myeloid cells-1), Heparin binding protein (HBP) and lipopolysaccharide-binding protein (LBP).

Figure 1: Stimulation of PCT production

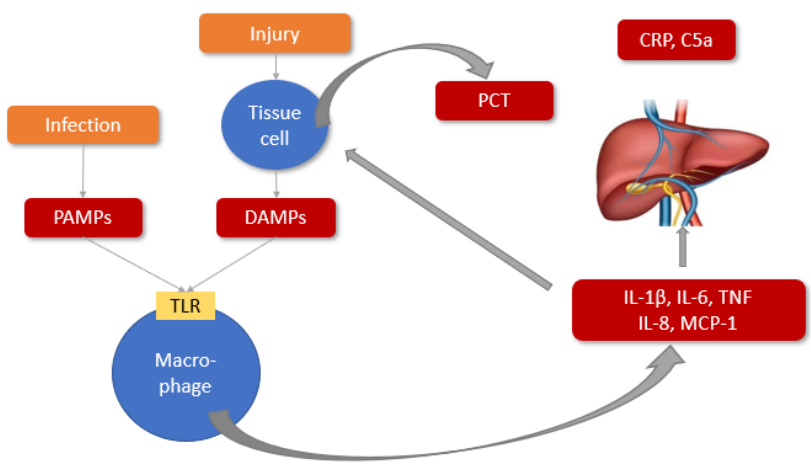

Studies have shown that PCT levels rise early, at the onset of sepsis, in comparison to CRP which has conventionally been in use as a biomarker ${ }^{8,9}$. Our study was conducted to assess elevated PCT levels in sepsis and its correlation with prognosis. PCT levels in healthy individuals, localized infection, sepsis and severe sepsis are shown in Figure $2^{10}$.

Figure 2: Interpretation of PCT levels

\begin{tabular}{|c|c|}
\hline PCT $<0.05 \mu g / L$ & \\
\hline Healthy individuals & $\begin{array}{l}\text { Determination of normal values with a high sensitive } \\
\text { assay revealed normal values to be below } 0.05 \mu g / L \text {. }\end{array}$ \\
\hline PCT $<0.5 \mu g / L$ & \\
\hline $\begin{array}{l}\text { Systemic infection (sepsis) } \\
\text { is not likely. }\end{array}$ & $\begin{array}{l}\text { Low risk for progression to severe systemic infection } \\
\text { (severe sepsis). }\end{array}$ \\
\hline Local bacterial infection is possible. & $\begin{array}{l}\text { Caution: PCT levels below } 0.5 \text { ug/L do not exclude } \\
\text { an infection, because localized infections (without } \\
\text { systemic signs) may be associated with such low levels. } \\
\text { Asso if the PCT measurement is done very early after a } \\
\text { following bacterial challenge (usually < } 6 \text { hours), these } \\
\text { values may still be low. In this case, PCT should be } \\
\text { re-assessed } 6-24 \text { hours later. }\end{array}$ \\
\hline $\mathrm{PCT} \geq 0.5-<2 \mu \mathrm{g} / \mathrm{L}$ & \\
\hline $\begin{array}{l}\text { Systemic infection (sepsis) } \\
\text { is possible, but various conditions } \\
\text { are known to induce PCT as well." }\end{array}$ & $\begin{array}{l}\text { Moderate risk for progression to severe systemic } \\
\text { infection (severe sepsis). The patient should be closely } \\
\text { monitored both clinically and by re-assessing PCT } \\
\text { within 6-24 hours. }\end{array}$ \\
\hline PCT $\geq 2-<10 \mu g / L$ & \\
\hline $\begin{array}{l}\text { Systemic infection (sepsis) is likely, } \\
\text { unless other causes are known." }\end{array}$ & $\begin{array}{l}\text { High risk for progression to severe systemic infection } \\
\text { (severe sepsis). }\end{array}$ \\
\hline PCT $\geq 10 \mu g / L$ & \\
\hline $\begin{array}{l}\text { Important systemic inflammatory } \\
\text { response, almost exclusively due to } \\
\text { severe bacterial sepsis or septic shock. }\end{array}$ & High likelihood of severe sepsis or septic shock. \\
\hline
\end{tabular}




\section{Objectives}

1. To assess the prevalence of elevated serum procalcitonin in patients with sepsis

2. Correlation of elevation in serum procalcitonin with patient characteristics, clinical course, severity, prognosis (assessed using qSOFA and SOFA score) and treatment outcome of sepsis.

\section{Inclusion Criteria}

Patients -

○ More than 18 years of age,

o for whom consent is obtained from patient or attendant,

- Meeting the ACCP/SCCM/ESICM International Consensus Definitions criteria for diagnosis of sepsis, and, with blood samples drawn within 12 hours of presentation with/ diagnosis of sepsis.

\section{Exclusion Criteria}

Patients with -
○ major burns
- severe trauma
○ acute inhalational injury
- major abdominal or cardiothoracic surgery
- acute multiorgan failure
- medullary thyroid carcinoma
○ pancreatitis
$\circ$ untreated end-stage renal failure.

\section{Materials and Methods}

A prospective, observational study was conducted among 40 patients admitted with a diagnosis of sepsisin the medical ICU of Rajah Muthiah Medical College Hospital during the study period from September 2018 to August 2020.

A detailed patient history along with examination findings were entered in the case proforma. qSOFA score was calculated from GCS, respiratory rate and systolic blood pressure. Shock index was calculated using heart rate and systolic blood pressure.
Laboratory Method: A venous sample of $2.5 \mathrm{ml}$ blood drawn within 12 hours of admission or diagnosis of sepsis was sent for estimating serum procalcitonin levels. These samples were processed by an automatic blood analyser which employed chemiluminescenceas method of analysis.

Routine investigations done as part of the workup of patient were considered. Using clinical data and investigations, SOFA score and APACHE II score were calculated.

The course of each patient during their ICU stay, the need for ventilatory support, inotropes and higher antibiotics, and treatment outcomes were followed up. Radiology and culture/sensitivity reports pertaining to the localization and causative organism of sepsis were recorded.

Informed written consent was obtained from the patients or attendants before including them in the study. Approval from the Institutional Human Ethics Committee was obtained prior to the study. The data obtained was entered into a Microsoft Excel worksheet and statistical analyses were performed using a statistical software package (Statistical Package for Social Sciences, SPSS). Comparisons of continuous data and categorical data between two groups were performed by t- test and Chi-square test respectively. Comparisons of continuous data among more than two groups were performed by ANOVA test. Pearson's correlation was used for correlation analysis. $\mathrm{P}$ value less than 0.05 were considered as statistically significant. 
Results

Table 1: Patient Characteristics

\begin{tabular}{|c|c|c|c|c|c|}
\hline \multicolumn{2}{|c|}{ Variables } & $\begin{array}{c}\text { Study subjects } \\
(\mathrm{n}=\mathbf{4 0})\end{array}$ & $\begin{array}{c}\text { Survivors } \\
(\mathbf{n}=\mathbf{3 0})\end{array}$ & $\begin{array}{c}\text { Non-survivors } \\
(\mathbf{n}=10)\end{array}$ & p-value \\
\hline \multicolumn{2}{|c|}{ Age (mean) } & $\begin{array}{c}62.1 \\
( \pm 14.25) \\
\end{array}$ & $\begin{array}{c}66.07 \\
( \pm 11.89) \\
\end{array}$ & $\begin{array}{c}50.2 \\
( \pm 14.64) \\
\end{array}$ & $<0.05$ \\
\hline \multirow[b]{2}{*}{ Sex } & Male & $19(48 \%)$ & $16(53 \%)$ & $3(30 \%)$ & $>0.05$ \\
\hline & Female & $21(52 \%)$ & $14(47 \%)$ & $7(70 \%)$ & $>0.05$ \\
\hline $\begin{array}{r}\text { Sourc } \\
0 \\
0 \\
0 \\
0 \\
0 \\
\end{array}$ & $\begin{array}{l}\text { of infection } \\
\text { Respiratory tract } \\
\text { Soft tissue } \\
\text { GIT } \\
\text { Urinary tract } \\
\text { Others } \\
\end{array}$ & $\begin{array}{l}18(45 \%) \\
9(22.5 \%) \\
5(12.5 \%) \\
5(12.5 \%) \\
3(7.5 \%) \\
\end{array}$ & $\begin{array}{c}13(43.3 \%) \\
8(26.7 \%) \\
2(6.7 \%) \\
5(16.7 \%) \\
2(6.6 \%) \\
\end{array}$ & $\begin{array}{l}5(50 \%) \\
1(10 \%) \\
3(30 \%) \\
0(0 \%) \\
1(10 \%) \\
\end{array}$ & $>0.05$ \\
\hline $\begin{array}{r}\text { Cause } \\
\circ \\
\circ \\
\circ \\
\circ \\
\circ \\
\circ \\
\end{array}$ & $\begin{array}{l}\text { ve organism } \\
\text { Gram positive } \\
\text { Gram negative } \\
\text { Anaerobic } \\
\text { Mixed } \\
\text { Others } \\
\text { Not isolated }\end{array}$ & $\begin{array}{c}6(15 \%) \\
17(42.5 \%) \\
1(2.5 \%) \\
6(15 \%) \\
2(5 \%) \\
8(20 \%) \\
\end{array}$ & $\begin{array}{c}5(16.7 \%) \\
13(43.3 \%) \\
1(3.3 \%) \\
4(13.4 \%) \\
1(3.3 \%) \\
6(20 \%) \\
\end{array}$ & $\begin{array}{l}1(10 \%) \\
4(40 \%) \\
0(0 \%) \\
2(20 \%) \\
1(10 \%) \\
2(20 \%) \\
\end{array}$ & $>0.05$ \\
\hline $\begin{array}{r}\text { Como } \\
\circ \\
\circ \\
\circ \\
\circ \\
\circ \\
\circ \\
\circ \\
\end{array}$ & $\begin{array}{l}\text { bid illnesses } \\
\text { Diabetes } \\
\text { Hypertension } \\
\text { CKD } \\
\text { COPD/ Asthma } \\
\text { Multiple } \\
\text { None } \\
\text { Other } \\
\end{array}$ & $\begin{array}{c}7(17.5 \%) \\
2(5 \%) \\
1(2.5 \%) \\
2(5 \%) \\
21(52.5 \%) \\
5(12.5 \%) \\
2(5 \%) \\
\end{array}$ & $\begin{array}{c}4(13.4 \%) \\
1(3.3 \%) \\
1(3.3 \%) \\
2(6.7 \%) \\
18(60 \%) \\
3(10 \%) \\
1(3.3 \%) \\
\end{array}$ & $\begin{array}{l}3(30 \%) \\
1(10 \%) \\
0(0 \%) \\
0(0 \%) \\
3(30 \%) \\
2(20 \%) \\
1(10 \%) \\
\end{array}$ & $>0.05$ \\
\hline $\begin{array}{r}\text { Sever } \\
\circ \\
\circ \\
\circ \\
\end{array}$ & $\begin{array}{l}\text { of sepsis } \\
\text { Sepsis } \\
\text { Severe sepsis } \\
\text { Septic shock } \\
\end{array}$ & $\begin{array}{c}8(20 \%) \\
16(40 \%) \\
16(40 \%)\end{array}$ & $\begin{array}{r}8(26.7 \%) \\
16(53.3 \%) \\
6(20 \%) \\
\end{array}$ & $\begin{array}{c}0(0 \%) \\
0(0 \%) \\
10(100 \%)\end{array}$ & $<0.001$ \\
\hline $\begin{array}{r}\text { Serun } \\
\circ \\
\circ \\
\circ \\
\circ \\
\end{array}$ & $\begin{array}{l}\text { PCT }(\text { ng/ml }) \\
<0.5 \\
\geq 0.5 \text { to }<2 \\
\geq 2 \text { to }<10 \\
\geq 10\end{array}$ & $\begin{array}{c}4(10 \%) \\
17(42.5 \%) \\
14(35 \%) \\
5(12.5 \%) \\
\end{array}$ & $\begin{array}{r}4(13.3 \%) \\
16(53.4 \%) \\
7(23.3 \%) \\
3(10 \%) \\
\end{array}$ & $\begin{array}{l}0(0 \%) \\
1(10 \%) \\
7(70 \%) \\
2(20 \%) \\
\end{array}$ & $<0.05$ \\
\hline $\begin{array}{r}\text { SOFA } \\
\circ \\
\circ \\
\circ \\
\circ \\
\circ \\
\circ \\
\end{array}$ & $\begin{array}{l}\text { core } \\
0 \text { to } 3 \\
4 \text { to } 5 \\
6 \text { to } 7 \\
8 \text { to } 9 \\
10 \text { to } 11 \\
>11 \\
\end{array}$ & $\begin{array}{c}8(20 \%) \\
5(12.5 \%) \\
6(15 \%) \\
11(27.5 \%) \\
5(12.5 \%) \\
5(12.5 \%)\end{array}$ & $\begin{array}{l}8(26.7 \%) \\
5(16.7 \%) \\
5(16.7 \%) \\
7(23.3 \%) \\
3(10 \%) \\
2(6.6 \%) \\
\end{array}$ & $\begin{array}{l}0(0 \%) \\
0(0 \%) \\
1(10 \%) \\
4(40 \%) \\
2(20 \%) \\
3(30 \%) \\
\end{array}$ & $<0.05$ \\
\hline $\begin{array}{r}\text { CRP } \\
\circ \\
\circ \\
\circ \\
\circ \\
\end{array}$ & $\begin{array}{l}\mathbf{g} / \mathbf{d l} \mathbf{l} \\
1 \text { to } 10 \\
11 \text { to } 20 \\
21 \text { to } 30 \\
>30\end{array}$ & $\begin{array}{c}20(50 \%) \\
12(30 \%) \\
7(17.5 \%) \\
1(2.5 \%) \\
\end{array}$ & $\begin{array}{c}18(60 \%) \\
8(26.7 \%) \\
4(13.3 \%) \\
0(0 \%)\end{array}$ & $\begin{array}{l}2(20 \%) \\
4(40 \%) \\
3(30 \%) \\
1(10 \%) \\
\end{array}$ & $<0.05$ \\
\hline $\begin{array}{r}\text { qSOF } \\
\circ \\
\circ \\
\circ \\
\circ \\
\end{array}$ & $\begin{array}{l}\text { score } \\
0 \\
1 \\
2 \\
3 \\
\end{array}$ & $\begin{array}{c}4(10 \%) \\
19(47.5 \%) \\
13(32.5 \%) \\
4(10 \%)\end{array}$ & $\begin{array}{r}4(13.3 \%) \\
14(46.7 \%) \\
11(36.7 \%) \\
1(3.3 \%) \\
\end{array}$ & $\begin{array}{l}0(0 \%) \\
5(50 \%) \\
2(20 \%) \\
3(30 \%) \\
\end{array}$ & $>0.05$ \\
\hline \multicolumn{2}{|c|}{$\begin{array}{cl}\text { APACHE II score } \\
\circ & 0 \text { to } 9 \\
\circ & 10 \text { to } 19 \\
\circ & 20 \text { to } 29 \\
\circ & \geq 30\end{array}$} & $\begin{array}{l}4(10 \%) \\
16(40 \%) \\
14(35 \%) \\
6(15 \%)\end{array}$ & $\begin{aligned} & 3(10 \%) \\
& 11(36.7 \%) \\
& 11(36.7 \%) \\
& 5(16.6 \%)\end{aligned}$ & $\begin{array}{l}1(10 \%) \\
5(50 \%) \\
3(30 \%) \\
1(10 \%)\end{array}$ & $>0.05$ \\
\hline
\end{tabular}




\begin{tabular}{|c|c|c|c|c|c|}
\hline \multicolumn{6}{|c|}{ ICU stay (days) } \\
\hline o & 1 to 5 & $20(50 \%)$ & $13(43.3 \%)$ & $7(70 \%)$ & \multirow{4}{*}{$>0.05$} \\
\hline 0 & 6 to 10 & $17(42.5 \%)$ & $16(53.4 \%)$ & $1(10 \%)$ & \\
\hline & 11 to 15 & $1(2.5 \%)$ & $1(3.3 \%)$ & $0(0 \%)$ & \\
\hline ○ & $>15$ & $2(5 \%)$ & $0(0 \%)$ & $2(20 \%)$ & \\
\hline \multicolumn{2}{|c|}{ Shock index } & & & & \multirow{3}{*}{$>0.05$} \\
\hline 0 & $<0.8$ & $11(27.5 \%)$ & $9(30 \%)$ & $2(20 \%)$ & \\
\hline 은 & $\geq 0.8$ & $29(72.5 \%)$ & $21(70 \%)$ & $8(100 \%)$ & \\
\hline \multicolumn{2}{|c|}{ MAP } & & & & \multirow{3}{*}{$>0.05$} \\
\hline o & $<65$ & $9(22.5 \%)$ & $5(16.7 \%)$ & $4(40 \%)$ & \\
\hline 0 & $\geq 65$ & $31(77.5 \%)$ & $25(83.3 \%)$ & $6(60 \%)$ & \\
\hline
\end{tabular}

Table 2: Correlation Statistics

\begin{tabular}{|l|c|c|}
\hline \multirow{2}{*}{ Parameters } & \multicolumn{2}{|c|}{ PCT (ng/ml) } \\
\cline { 2 - 3 } & $\mathbf{R}$ & P VALUE \\
\hline Severity of sepsis & $1.2372(\mathrm{~F}$ value $)$ & $>0.05$ \\
\hline SOFA score & 0.0679 & $>0.05$ \\
\hline CRP $(\mathrm{mg} / \mathrm{dl})$ & 0.7086 & $<0.001$ \\
\hline qSOFA score & 0.3467 & $<0.05$ \\
\hline APACHE II score & 0.127 & $>0.05$ \\
\hline Duration of ICU stay & -0.0698 & $>0.05$ \\
\hline Shock index & 0.1098 & $>0.05$ \\
\hline MAP $(\mathrm{mmHg})$ & -0.1321 & $>0.05$ \\
\hline
\end{tabular}

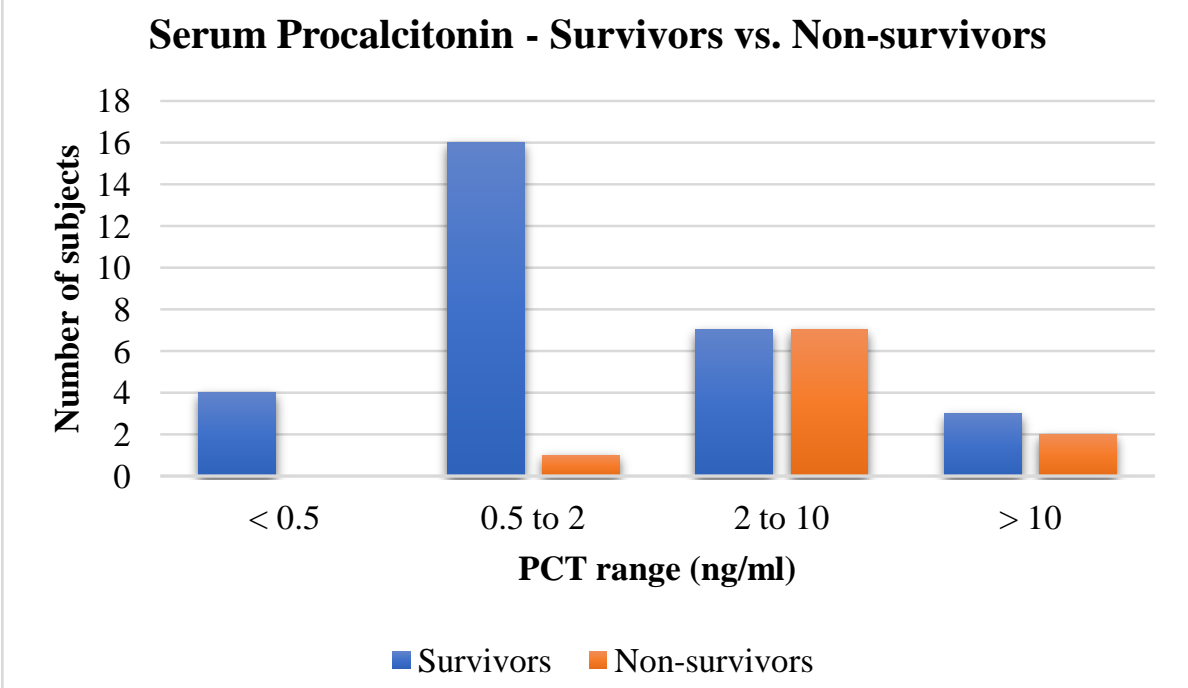

Graph 1: Serum procalcitonin levels vs. Mortality 


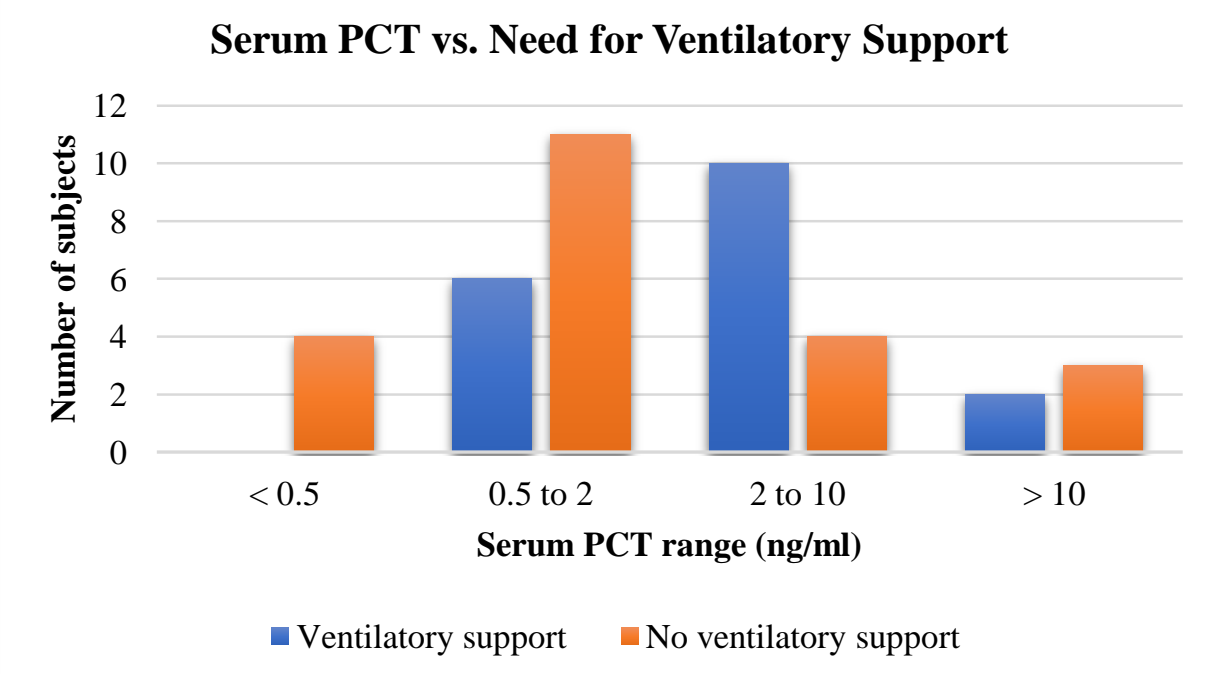

Graph 2: Serum procalcitonin levels and ventilatory support

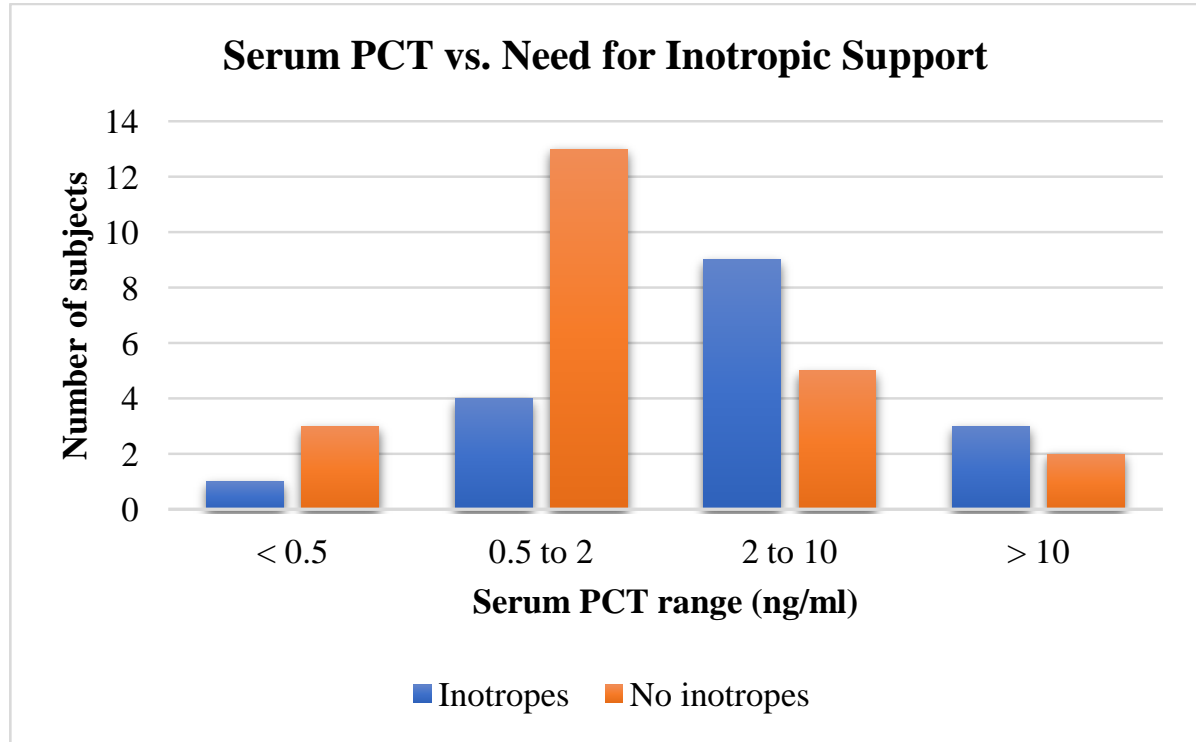

Graph 3: Serum procalcitonin levels and inotropic support

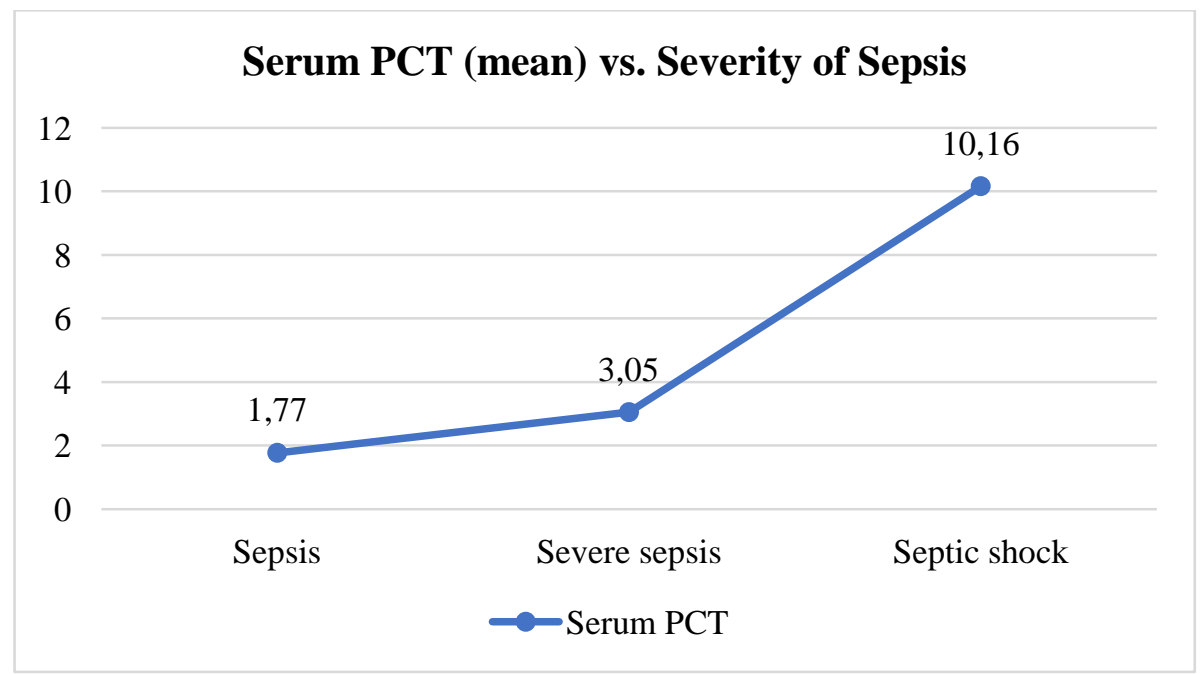

Graph 4: Serum procalcitonin levels (mean) vs. severity of sepsis 


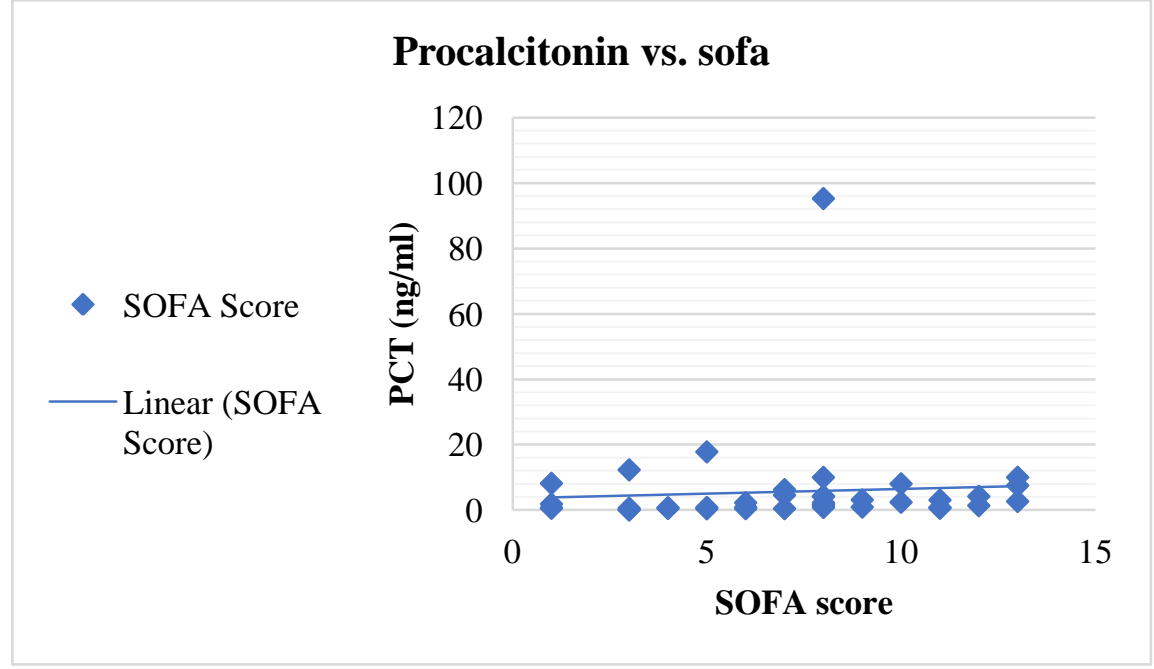

Graph 5: Correlation between SOFA score and PCT

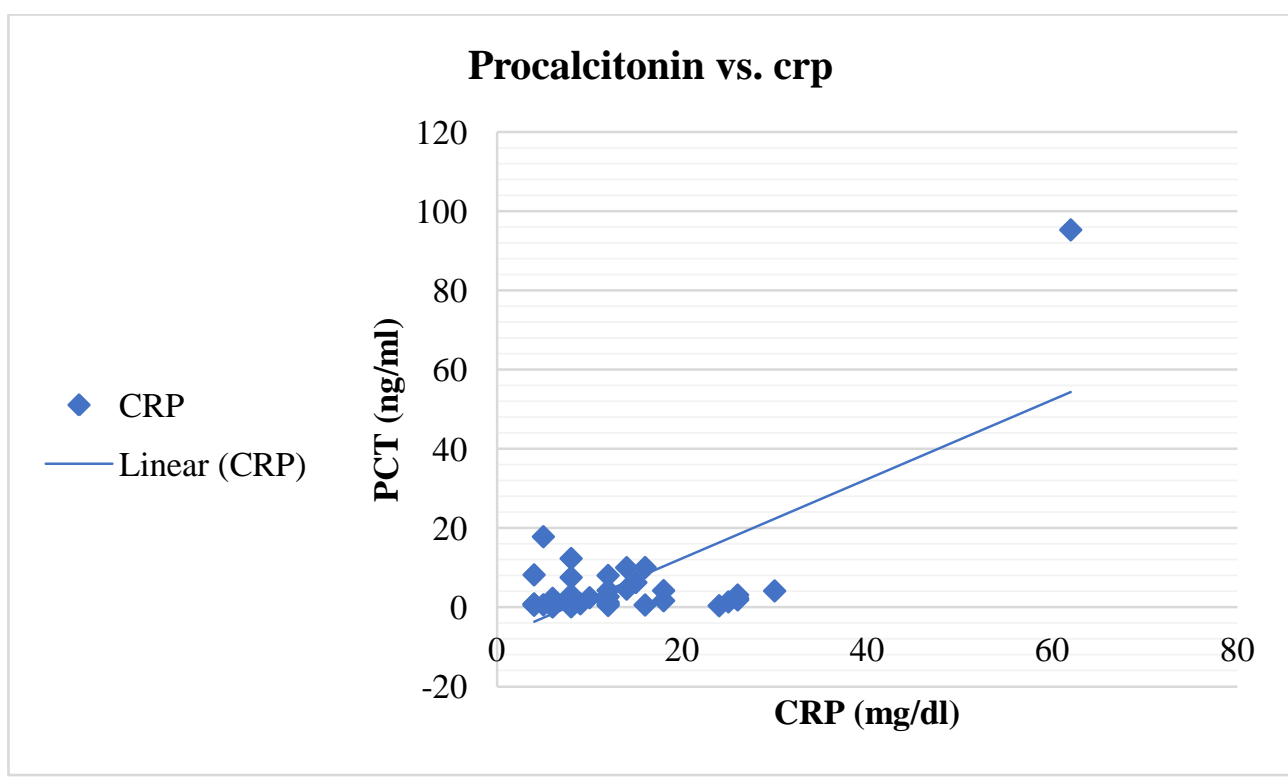

Graph 6: Correlation between CRP and PCT

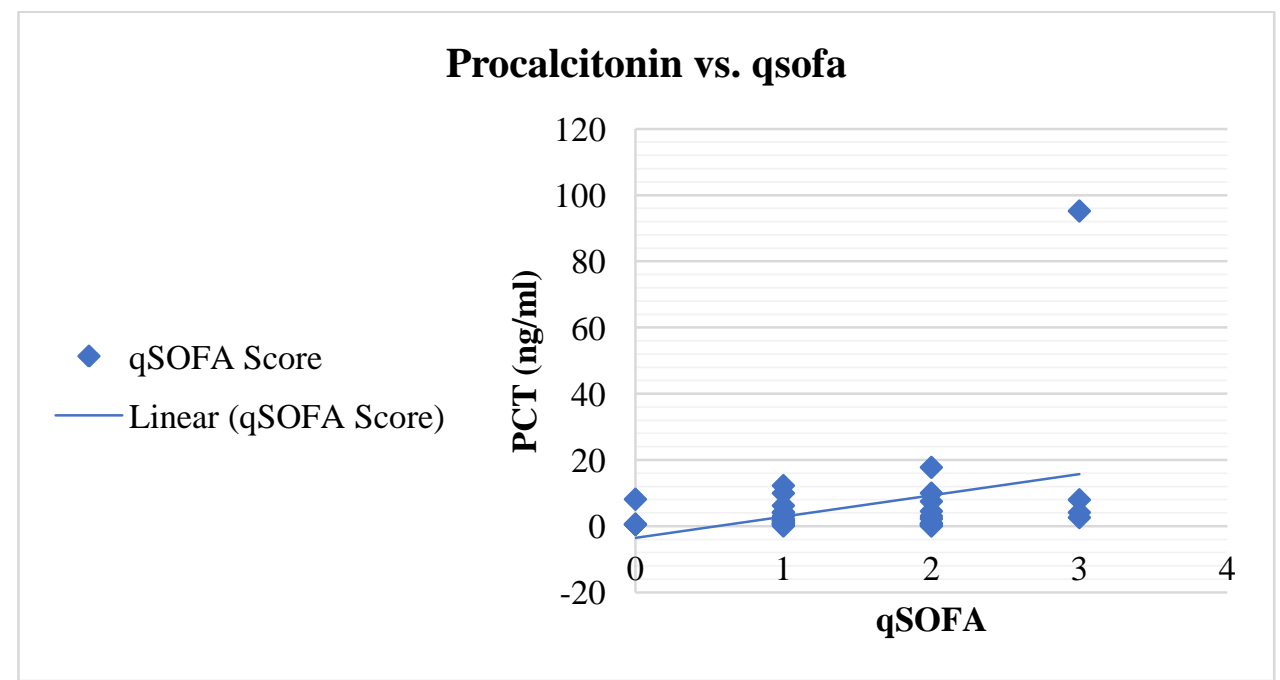

Graph 7: Correlation between qSOFA and PCT 
Among the 40 sepsis patients studied, $48 \%$ were males $(n=19)$ and $52 \%$ were females $(n=21)$. The majority of patients belonged to the 60 to 70 years age group with a mean age of $62.1 \pm 14.25$ years. Diabetes was the most prevalent individual comorbidity in the study subjects $(17.5 \%, \mathrm{n}=7)$, followed by hypertension (5\%, $\mathrm{n}=2) .52 .5 \%$ subjects $(n=21)$ had multiple comorbidities.

The most common source of sepsis was the respiratory tract $(45 \%, \mathrm{n}=18)$, followed by soft tissue $(22.5 \%, \mathrm{n}=9)$. Gram negative organisms were the major cause of sepsis $(42.5 \%, \mathrm{n}=17)$, followed by Gram positive organisms and mixed infections $-15 \%$ each $(n=6)$. Anaerobic organisms caused $2.5 \%(n=1)$ of infections and $20 \%(n=8)$ were culture-negative (Table 1). The above characteristics, except for age, did not have a significant association with mortality.

On grading severity of sepsis, $20 \%$ patients had sepsis $(n=8), 40 \%$ each severe sepsis and septic shock ( $n=16$ in each category). The greater the severity of sepsis, the greater was the mortality ( $p$ $<0.001) .100 \%(n=10)$ of non-survivors in our study succumbed to septic shock.

The overall mortality from sepsis in the study was $25 \%(\mathrm{n}=10)$.

The mean PCT of study subjects was $5.64 \pm 15.05$ $\mathrm{ng} / \mathrm{ml}$. The majority of survivors $(53.4 \%)$ had PCT in the range 0.5 to $2 \mathrm{ng} / \mathrm{ml}(\mathrm{n}=16)$, in contrast to non-survivors, the majority of whom had PCT in the range 2 to $10 \mathrm{ng} / \mathrm{ml}(70 \%, \mathrm{n}=7)$. The mean PCT of survivors was $2.75 \pm 4.10 \mathrm{ng} / \mathrm{ml}$ compared to $14.29 \pm 28.57 \mathrm{ng} / \mathrm{ml}$ in non-survivors $(p<0.05)$ (Graph 1).

$55.6 \%$ of the patients who needed ventilatory support had PCT between 2 to $10 \mathrm{ng} / \mathrm{ml}$. Hence, higherserum PCT was associated with need for ventilatory support (mean $8.86 \pm 21.78 \mathrm{ng} / \mathrm{ml}$ ) compared to those who did not need ventilatory support (mean $2.99 \pm 4.52 \mathrm{ng} / \mathrm{ml}, p<0.05$ ) (Graph 2). Similarly, the patients who needed inotropic support had higher PCT values (mean $9.61 \pm 2.29$ $\mathrm{ng} / \mathrm{ml}$ ) than those who did not (mean $2.70 \pm 4.36$, $p>0.05)($ Graph 3). PCT levels also increased with increasing severity of sepsis: the mean PCT was
$1.77 \pm 2.66 \mathrm{ng} / \mathrm{ml}$ in sepsis, compared to $3.05 \pm$ $4.29 \mathrm{ng} / \mathrm{ml}$ in severe sepsis, and $10.16 \pm 22.90$ $\mathrm{ng} / \mathrm{ml}$ in septic shock(Graph 4).

SOFA score in non-survivors was $9.80 \pm 2.10$, compared to $6.20 \pm 3.45$ in survivors $(p<0.05)$. The mean CRP of survivors was $10.5 \pm 6.35$ $\mathrm{mg} / \mathrm{dl}$ compared to $21.80 \pm 16.02 \mathrm{mg} / \mathrm{dl}$ in nonsurvivors $(p<0.05)$. SOFA score had weak positive correlation $(p>0.05)$ and CRP had strong positive correlation with PCT $(p<0.05)($ Graph 5 and 6).

Non-survivors had mean qSOFA of $1.80 \pm 0.92$ and survivors had mean qSOFA of $1.30 \pm 0.75$ ( $p$ $>0.05)$. qSOFA score had weak positive correlation with PCT $(p<0.05)($ Graph 7).Majority of survivors and non-survivors had APACHE II score in the 10 to 19 range. APACHE II score had weak positive correlation with PCT $(p>0.05)$, but did not demonstrate significant association with mortality.

Median duration of ICU stay among our patients was 5.5 days. $70 \%(n=7)$ of non-survivors died within 5 days of admission in ICU, and $20 \%(n=2)$ died after more than 15 days of ICU stay. Median ICU stay in non-survivors and survivors was 2.5 days and 6.5 days respectively. In our study, duration of ICU stay had weak negative correlation with PCT $(p>0.05)$.

Shock index (normal range 0.5 to 0.7 , with index $\geq 0.8$ indicating worse prognosis) was $\geq 0.8$ in $80 \%$ ( $\mathrm{n}=8$ ) of non-survivors, compared to $70 \%$ of survivors $(\mathrm{n}=21, p>0.05)$. Shock index had weak positive correlation with PCT $(p>0.05) .40 \%$ of non-survivors $(n=4)$ had mean arterial pressure (MAP) $<65 \mathrm{mmHg}$ (ideal target MAP for best outcome in sepsis being $\geq 65 \mathrm{mmHg}$ ) compared to $16.7 \%(\mathrm{n}=5)$ of survivors $(p>0.05)$. MAP showed weak negative correlation with PCT $(p>0.05)$ (Graph 8).

\section{Discussion}

- The majority of sepsis cases were in the 50 to 70 years age group. The male-female ratio was 1.1:1. 
○ In concurrence with the findings of other similar studies, respiratory tract was the commonest source of infection (45\% vs. $48 \%$ in the study by Harbarth et $a l^{11}$ and $49 \%$ in the study by Suprinet $a l^{12}$ ). It was followed by soft tissue infections, gastrointestinal tract and urinary tract infections.

○ Gram-negative organisms $(42.5 \%)$ were the major cause of sepsis, followed by Gram-positive organisms (15\%) and mixed infections (15\%). Anaerobic and yeast infections constituted a minor proportion of cases. Gram negative organisms were also observed to be most commonly causative in the studies by Harbarth et $a l^{11}$ and Suprin et $a l^{12}$ (53\% and $39 \%$ respectively). Anaerobes caused $2.5 \%$ of infections in the present study compared to $1.3 \%$ in the Suprinet al study ${ }^{12}$. The proportion of cases with mixed growth $(15 \%)$ was also similar $(9 \%$ in the Harbath et $a l^{11}$ study and $8 \%$ in the Suprin et al study $^{12}$ ). Gram positive organisms were isolated in $15 \%$ in the present study compared to $38 \%, 22 \%$ and $29 \%$ in the Harbath et al study ${ }^{11}$, MOSES study ${ }^{13}$ and the Suprin et al study ${ }^{12}$ respectively. $20 \%$ patients were culture-negative, similar to $27 \%$ in the Harbath et al study ${ }^{11}$ and $16 \%$ in the Suprinet al study ${ }^{12}$. The MOSES study $^{13}$ had greater number of culturenegative cases (67\%).

○ Among comorbid illnesses, diabetes $(17.5 \%)$ followed by hypertension (5\%) were more prevalent in our study, whereas hypertension (62\%) was more common than diabetes (34\%) in the MOSES study $^{13}$. Multiple comorbid conditions existed in $53 \%$ of our study subjects. Diabetes and multiple comorbidities were each present in $30 \%$ of non-survivors in our study $(p>0.05)$.

- The gender, source of sepsis, causative organism and comorbid illness had no statistically significant association with mortality from sepsis.

○ On grading severity of sepsis, the incidence of sepsis was $20 \%$, while incidence of severe sepsis and septic shock were $40 \%$ each.

- A significant association between mortality and severity of sepsis was observed.

- Higher PCT levels were associated with greater severity of sepsis, mortality from sepsis, increased need for ventilatory support $(p<0.05)$ and inotropic support $(p$ $>0.05$ ).

- SOFA score and CRP levels were found to be good independent predictors of mortality in sepsis $(p<0.05)$, showing positive correlation with PCT values ( $p$ $>0.05, p<0.001$ ).

o Higher qSOFA score and shock index $\geq$ 0.8 were also seen more often in nonsurvivors in our study, both showing a weak positive correlation with PCT levels $(p<0.05, p>0.05)$.

- APACHE II score was not a good predictor of mortality in our study, consistent with findings of the study by Brunkhorst et al ${ }^{14,15}$.

- MAP and duration of ICU stay demonstrated negative correlation with PCT values in our study, as patients with MAP $<65 \mathrm{mmHg}$ andthe patients who died of sepsis in the first few days of admission had higher PCT values.

\section{Limitations}

The study did not evaluate surgical causes of sepsis as the sample was limited to patients admitted in the medical ICU. Statistical significance for some correlations could not be demonstrated due to the smaller sample size from a single centre. Serial measurements of PCT levels may be of better aid in assessing response to treatment, which could not be done due to financial constraints. 


\section{Conclusion}

It may be inferred from our study findings that serum procalcitonin (PCT) is an excellent tool in early diagnosis of sepsis, where existing methods like culture, SOFA score and CRP levels fall short by a wide margin ${ }^{9,16}$. A sensitivity and specificity of up to $97 \%$ and $78 \%$ respectively for PCT have been described in the literature ${ }^{11}$.

Serum procalcitonin served as a good indicator of in-hospital mortality with $>2 \mathrm{ng} / \mathrm{ml}$ as an ideal cut-off, as $90 \%$ of patients who died of sepsis in our study had serum PCT > $2 \mathrm{ng} / \mathrm{ml}$. Greater levels of PCT were also associated with need for ventilatory or inotropic support.

Our study also demonstrates PCT values correlate with the severity of sepsis, levels > $2 \mathrm{ng} / \mathrm{ml}$ occurring commonly in septic shock. Thus, serum PCT is also a tool to risk stratify the patient according to prognosis, so that available resources may be utilized effectively in patient care.

Levels of PCT were also found to fall with successful treatment of sepsis and improvement of the patient's condition. Hence, serial monitoring would be useful in an ICU setting ${ }^{17-19}$.

Therefore, with the current trend of increasing morbidity and mortality from sepsis globally, a biomarker like serum procalcitonin for diagnosis and prognostication of sepsis is the need of the hour.

\section{References}

1. Na S, Kuan WS, Mahadevan M, Li CH, Shrikhande P, Ray S, et al. Implementation of early goal-directed therapy and the surviving sepsis campaign resuscitation bundle in Asia. Int $\mathrm{J}$ Qual Health Care. 2012; 24: 452-462. doi: 10.1093/intqhc/mzs045 PMID: 22899698

2. Bone RC, Grodzin CJ, Balk RA. Sepsis: a new hypothesis for pathogenesis of the disease process. Chest 1997;112:235-43.

3. Andersson U, Tracey KJ (2003) HMGB1 in sepsis. Scand J Infect Dis 35:577-584

4. Hofer N, Zacharias E, Muller W, Resch B. An update on the use of C-reactive protein in early-onset neonatal sepsis: current insights and new tasks. Neonatology 2012;102:25-36.

5. Müller B, White JC, Nylén ES, Snider RH, Becker KL, Habener JF (2001). Ubiquitous expression of the calcitonin gene in multiple tissues in response to sepsis. J ClinEndocrinol Metab 86: 396404.

6. Nylén ES, Snider RH, Thompson BS, Rohatgi P, Becker KL (1996). Pneumonitis-associated

hyperprocalcitonemia. Am J Med Sci 312: 12-18.

7. Whang KT, Vath SD, Becker KL, Snider RH, Nylen ES, Muller B et al. (2000). Procalcitonin and pro-inflammatory cytokine interactions in sepsis. Shock 14: 73-78.

8. Jensen JU, Heslet L, Hartvig T, Espersen K, Steffensen P, Tvede M (2006). Procalcitonin increase in early identification of critically ill patients at high risk of mortality. Crit Care Med 34: 2596-2602.

9. Maki DG, Kluger DM, Crnich CJ (2006). The risk of bloodstream infection in adults with different intravascular devices: a systematic review of 200 published prospective studies. Mayo ClinProc 81: 1159-1171

10. Becker KL, Snider RH, Nylén ES (2007). Procalcitonin assay in systemic inflammation infection, and sepsis: clinical utility and limitations. Crit Care Med 36: 941-952.

11. Harbarth S, Holeckova K, Froidevaux C, et al (2001) Diagnostic value of procalcitonin, interleukin-6, and interleukin-8 in critically ill patients admitted with suspected sepsis. Am J Respir Crit Care Med 164:396-340

12. Suprin E, Camus C, Gacouin A, et al. Procalcitonin: a valuable indicator of 
infection in a medical ICU? Intensive Care Med 2000; 26: 1232-8.

13. Schuetz P, Birkhahn R, Sherwin R, et al. Serial procalcitonin predicts mortality in severe sepsis patients: results from the Multicenter Procalcitonin Monitoring SEpsis (MOSES) Study. Crit Care Med 2017; 45: 781-89.

14. Brunkhorst FM, Wegschneider K, Forycki ZF, Brunkhorst R. Procalcitonin for early diagnosis and differentiation of SIRS, sepsis, severe sepsis, and septic shock. Intensive Care Med 2000;26:S148-S152.

15. Brunkhorst FM, Al-Nawas B, Krummenauer F, et al. Procalcitonin, creactive protein and APACHE II score for risk evaluation in patients with severe pneumonia. ClinMicrobiol Infect 2002;8:93-100.

16. Tang BMP, Eslick GD, Craig JC, McLean AS. Accuracy of procalcitonin for sepsis diagnosis in critically ill patients: systemic review and meta-analysis. Lancet Infect Dis 2007; 7: 210-17.

17. Martinez JM, Wagner KE, Snider RH, Nylen ES, Müller B, Sarani B et al. (2001). Late immunoneutralization of procalcitonin arrests the progression of lethal porcine sepsis. Surg Infect (Larchmt) 2: 193-201, discussion 202203.

18. Nylén ES, Whang KL, Steinwald PM, Snider RH, White JC, Becker KL(1998). Procalcitonin increases mortality and procalcitonin recognizing antiserum improves mortalityin an experimental model of sepsis. Crit Care Med 26: 10011006. (See Editorial 26: 977-978).

19. Stolz D, Christ-Crain M, Bingisser R, Leuppi J, Miedinger D, Müller C et al. (2007). Antibiotic treatment of exacerbations of COPD: a randomized, controlled trial comparing procalcitoninguidance with standard therapy. Chest 131: 9-19. 